\title{
TLR4 promotes the expression of HIF-1 $\alpha$ by triggering reactive oxygen species in cervical cancer cells in vitro-implications for therapeutic intervention
}

\author{
XIAO YANG ${ }^{1}$, GAN TAO CHEN ${ }^{2}$, YAN QING WANG $^{1}$, SHU XIAN $^{1}$, LI ZHANG $^{1}$, \\ SHAO MING ZHU ${ }^{3}$, FENG PAN ${ }^{4}$ and YAN XIANG CHENG ${ }^{1}$ \\ ${ }^{1}$ Department of Obstetrics and Gynecology, Renmin Hospital of Wuhan University, Wuhan, Hubei 430060; ${ }^{2}$ Department of \\ Gastroenterology, The Third Renmin Hospital of Xiantao City, Xiantao, Hubei 433000; Departments of ${ }^{3}$ Urology \\ and ${ }^{4}$ Orthopedics, Renmin Hospital of Wuhan University, Wuhan, Hubei 430060, P.R. China
}

Received June 15, 2017; Accepted October 4, 2017

DOI: $10.3892 / \mathrm{mmr} .2017 .8108$

\begin{abstract}
The present study investigated the mechanism underlying Toll-like receptor 4 (TLR4)-mediated stimulation of hypoxia-inducible factor- $1 \alpha(\mathrm{HIF}-1 \alpha)$ activity and its association with reactive oxygen species (ROS) in cervical cancer cells. SiHa cells were cultured and randomized to control, lipopolysaccharide (LPS), methyl- $\beta$-cyclodextrin $(\mathrm{M} \beta \mathrm{CD})+\mathrm{LPS}$, ammonium pyrrolidinedithiocarbamate (PDTC)+LPS, ST2825+LPS and small interfering (si) RNA TLR4+LPS treatment groups. Cell proliferation was quantified using an MTT assay, cell cloning was performed using soft agar colony formation and HIF-1 $\alpha$ expression was detected by immunocytochemical staining and western blot analyses. Dichloro-dihydro-fluorescein diacetate and lucigenin luminescence assays were used to detect alterations in ROS and nicotinamide-adenine dinucleotide phosphate (NADPH) oxidase content, respectively. Co-localization of TLR4 and HIF-1 $\alpha$ was detected by immunofluorescence staining and observed using fluorescence microscopy. Compared with the control group, cell proliferation was enhanced in the LPS-treated group and was not altered in the PDTC+LPS treatment group. Cell proliferation was reduced in all other treatment groups $(\mathrm{P}<0.05)$. Compared with the LPS group, cell proliferation decreased in all other groups. Compared with the PDTC+LPS treatment group, cell proliferation significantly decreased when LPS was co-administered with ST2825, siTLR4 and $\mathrm{M} \beta \mathrm{CD}(\mathrm{P}<0.01)$. Treatment with $\mathrm{M} \beta \mathrm{CD}+\mathrm{LPS}$ exhibited an increased inhibitory effect on cell activity and proliferation.
\end{abstract}

Correspondence to: Dr Yan Xiang Cheng, Department of Obstetrics and Gynecology, Renmin Hospital of Wuhan University, 99 Zhang Zhidong Road, Wuhan, Hubei 430060, P.R. China E-mail: doctornancy@qq.com

Key words: lipid raft, Toll-like receptor 4, cervical cancer, hypoxiainducible factor- $1 \alpha$
Compared with the control group, HIF-1 $\alpha$ expression was enhanced following treatment with LPS, although it decreased when LPS was co-administered with ST2825, siTLR4 and M $\beta C D(\mathrm{P}<0.05)$. HIF-1 $\alpha$ expression decreased following treatment with ST2825, siTLR4, M $\beta$ CD and PDTC+LPS, compared with treatment with LPS alone. Compared with the PDTC+LPS group, HIF-1 $\alpha$ activity decreased when LPS was co-administered with ST2825, siTLR4 and M $\beta C D$. NADPH oxidase and ROS levels increased in cells treated with LPS, compared with the control group, at 24 and $12 \mathrm{~h}$ following treatment, respectively, and decreased at $12 \mathrm{~h}$ when LPS was co-administered with ST2825, siTLR4 and M $\beta C D$. There was no difference between the LPS and PDTC+LPS groups with respect to NADPH and ROS levels. Compared with the PDTC+LPS group, NADPH oxidase activity and ROS content decreased when LPS was co-administered with ST2825, siTLR4 and M $3 C D$. NADPH oxidase activity and ROS content were lowest in the $\mathrm{M} \beta \mathrm{CD}+\mathrm{LPS}$ treatment group, and immunofluorescent staining demonstrated that TLR4 was localized to the cell surface and HIF-1 $\alpha$ was primarily localized to the cytoplasm. TLR4 was co-expressed with HIF-1 $\alpha$ in cervical cancer cells. The results of the present study suggested that TLR4 signaling primarily promoted HIF-1 $\alpha$ activity via activation of lipid rafts/NADPH oxidase redox signaling and may be associated with the initiation and progression of cervical cancer. This promoting effect was stronger in TLR4/lipid rafts/NADPH oxidase pathway than that in TLR4-NF- $\kappa$ B signaling pathway. Therefore, the TLR4/lipid raft-associated redox signal may be a target for therapeutic intervention to prevent the growth of cervical cancer.

\section{Introduction}

Cervical cancer is a common type of reproductive tumor with an incidence of $\sim 50$ million cases annually, $80 \%$ of which occur in developing countries. Cervical cancer is increasing in prevalence and the age of onset is decreasing (1). Therefore, understanding the initiation and progression of cervical cancer is required for prevention and the development of novel therapies. 
TLRs (Toll-like receptors) are pattern recognition receptors that regulate infection by identifying conserved molecules of pathogenic microorganisms. Previous studies indicated that TLRs are expressed on immune cells, in addition to normal epithelial cells and a number of tumor cells $(2,3)$. TLRs contribute to mucosal immunity, and tumor initiation and development $(4,5)$. TLR4 is a pattern recognition receptor that is able to recognize exogenous ligands, including lipopolysaccharide (LPS), present in gram negative bacteria cell walls, and is associated with tumor growth and inflammation, as other members of the same family (6).

The cervix is exposed to bacterial flora from the normal vaginal environment which, along with vaginal pathogens, stimulates cervical epithelial cells repeatedly during infection. Studies have indicated that the inflammatory response may directly regulate cell deterioration and contribute to the formation of a tumor microenvironment, indirectly modulating tumor initiation and development $(7,8)$. Pro-inflammatory cytokines and endogenous TLR ligands produced by tissues may activate the TLR pathway in tumor cells and promote tumor cell development, immune escape and apoptotic resistance $(9,10)$. A study suggested that TLR4 may be upregulated in cervical cancer cells compared with other TLRs (11) and that the expression of TLR4 increased markedly following simulation of cervical cancer cells with LPS. Therefore, downregulation of TLR4 may induce apoptosis in cervical cancer SiHa cells (12). TLR4 may be associated with the initiation and development of cervical cancer. An additional study demonstrated that TLR4 initiated cell activation to induce inflammation and tumors via MyD88- and nuclear factor $\kappa \mathrm{B}(\mathrm{NF}-\kappa \mathrm{B})$-associated signaling pathways, and that the activation of NF- $\mathrm{KB}$ may be involved in the initiation and development of cancer (13). In addition, when pathogen-associated molecular patterns bind to TLR4, activation of the TLR4 signaling pathway is modulated by mobile microdomains of membrane lipids known as lipid rafts (14). The above study indicated an interaction between lipid rafts and the TLR4 signaling pathway, and suggested that lipid rafts may serve a role in the initiation of the TLR4 signaling pathway.

Hypoxia inducible factor 1 (HIF-1) is a transcription factor involved in cell adaptive adjustment under hypoxia. HIF-1 is composed of HIF- $1 \alpha$ and $-1 \beta$ subunits, and HIF- $1 \alpha$ maintains the stability of HIF-1 expression, which affects energy metabolism, proliferation and apoptosis in tumor cells. HIF-1 additionally promotes tumor angiogenesis, increases tumor invasiveness, and increases resistance to radiotherapy and chemotherapy through its involvement in the transcriptional regulation of a number of target genes (15). Previous studies have demonstrated that the uncontrolled growth of cervical cancer cells may be associated with excessive activation of HIF- $1 \alpha$ and, therefore, HIF-1 $\alpha$ may be associated with cancer control mechanisms $(16,17)$. HIF-1 may mediate activation of telomerases in cervical cancer cells to promote cancer progression (18). Studies have indicated that HIF-1 $\alpha$ can not only promote tumor growth, but also enhance tumor cell invasion $(19,20)$. In one study, silencing HIF-1 $\alpha$ using small interfering (si)RNA in cervical cancer cells downregulated the expression of solute carrier family 2 member 1 and hexokinase 2, and reduced the glycolytic activity of tumors, promoting apoptosis and tumor cell growth inhibition (21).
The accumulation of HIF-1 induced by bacterial LPS in immune cells, including macrophages and monocytes, is TLR4-dependent (22). TLR4 expression was positively associated with HIF-1 $\alpha$ expression in cervical cancer cells and, therefore, the TLR4 signaling pathway may be involved in maintaining elevated HIF-1 $\alpha$ activity to promote cervical cancer development, although the mechanism underlying these observations remains to be elucidated (23). In the present study, HIF-1 $\alpha$ expression markedly increased in cervical cancer tissues in the presence of reactive oxygen species (ROS), and the increased ROS was derived from intracellular reduced nicotinamide-adenine dinucleotide phosphate (NADPH) oxidase, which caused the elevated intracellular HIF-1 $\alpha$ activity associated with cervical cell malignancy (24). The above observations may contribute to the recurrence of cancer following treatment for cervical cancer, and previous studies indicated that the activation of cervical epithelial membrane lipid rafts increased the transfer of NADPH oxidase subunits to lipid rafts, resulting in excessive activation of NADPH oxidase and increased intracellular ROS levels $(25,26)$. Therefore, TLR4 may promote increased HIF-1 $\alpha$ activity in cervical cancer cells due to lipid raft-mediated activation of the NADPH oxidase pathway.

To study the TLR4-mediated elevated activity of HIF-1 $\alpha$, different pathways in cervical cells were selectively inhibited using ST2825, pyrrolidine dithiocarbamate (PDTC) and methyl- $\beta$-cyclodextrin (M $\beta C D)$. ST2825 is a specific inhibitor of myeloid differentiation factor 88 (MyD88), which inhibits the dimerization of MyD88, and prevents the activation and transduction of the TLR signal, thereby inhibiting the TLR signaling pathway (27). PDTC is an inhibitor of the NF- $\mathrm{BB}$ signaling pathway, preventing degradation of the inhibitor of NF- $\kappa B$ subunit $\alpha(\mathrm{I} \kappa \mathrm{B})$, activation of NF- $\mathrm{KB}$ and translocation of NF- $\kappa B$ to the nucleus (28). M $\beta C D$ has a strong affinity for cholesterol, and is able to remove it from cells, and dysregulate lipid raft integrity and function (29).

The mechanisms underlying the TLR4-mediated activation of HIF-1 $\alpha$ via lipid rafts and redox events remain to be elucidated. Therefore, the present study aimed to elucidate these mechanisms and alterations in NADPH oxidase activity in response to the activation of TLR4 signaling. In the present study ROS levels in cervical cancer cells were measured following deregulation of the TLR4 signaling pathway and lipid raft function.

\section{Materials and methods}

Materials. Cervical carcinoma SiHa cells were purchased from Saiqi BiologicalEngineering Company (Shanghai,China). Fetal bovine serum (FBS), Minimum Essential Medium (MEM) and western blot analysis kits were purchased from Thermo Fisher Scientific, Inc. (Waltham, MA, USA). Immunohistochemistry staining diaminobenzidine (DAB) kits were purchased OriGene Technologies, Inc. (Beijing, China). MTT assay kits, protein quantification kits and ROS detection reagent kits were purchased from Beyotime Institute of Biotechnology (Jiangsu, China). The immunofluorescent staining kit was manufactured by OriGene Technologies, Inc. HiPerFect transfection reagent was manufactured by Qiagen China Co., Ltd. (Shanghai, China). Rabbit anti-human HIF-1 $\alpha$ monoclonal antibody 
(cat. no. ab51608) and mouse anti-human TLR4 monoclonal antibodies (cat. no. ab22048), and horseradish peroxidase (HRP)-labeled goat anti-rabbit immunoglobulin (Ig)G (cat. no. ab6721) were purchased from Abcam (Cambridge, UK). DyLight $^{\mathrm{TM}}$ 488-labeled goat anti-rabbit immunoglobulin (Ig)G (cat. no. ZF-0511) and DyLight ${ }^{\mathrm{TM}}$ 594-labeled goat anti-mouse IgG (cat. no. ZF-0513) were from OriGene Technologies, Inc.; HIF- $1 \alpha$ rabbit and $\beta$-actin rabbit polyclonal antibodies (cat. nos. PB0245 and BA2305) were purchased from Wuhan Boster Biological Technology, Ltd. (Wuhan, China). NADPH, lucigenin, LPS, PDTC, M $\beta$ CD and ST2825 were purchased from Sigma-Aldrich (Merck KGaA, Darmstadt, Germany). TLR4 siRNA (5-GGACCTCTCTCAGTGTCAA-3) was designed and synthesized by Shanghai Jima Industrial Co. Ltd. (Shanghai, China).

Cell cultures. The cervical cancer SiHa cells were cultured in MEM (4 ml) containing $10 \% \mathrm{FBS}$ at $5 \% \mathrm{CO}_{2}, 37^{\circ} \mathrm{C}$ and saturated humidity. Medium was replaced daily. When cells reached $80 \%$ confluency they were selected for subsequent experiments.

Treatment groups. SiHa cells were randomized into 6 groups: i) The untreated control group was normally cultured without treatment or stimulation; ii) the LPS control group was treated with $500 \mathrm{ng} / \mathrm{ml}$ LPS for 24, 48 or $72 \mathrm{~h}$; iii) lipid raft intervention, termed the M $\beta C D+L P S$ group was treated with $\mathrm{M} \beta \mathrm{CD}$ [5 mmol/l; dilution with MEM] and pre-incubated for $1 \mathrm{~h}$ prior to adding $500 \mathrm{ng} / \mathrm{ml} \mathrm{LPS}$; iv) the ST2825+LPS group was treated with ST2825 (5 mmol/l; dilution with MEM) and pre-incubated for $1 \mathrm{~h}$ prior to adding $500 \mathrm{ng} / \mathrm{ml} \mathrm{LPS}$; v) the siTLR4+LPS group was transfected with TLR4 siRNA using HiPerFect transfection reagent (when cells reached $50 \%$ confluency, transfection was confirmed and $500 \mathrm{ng} / \mathrm{ml}$ LPS was added; and vi) the NF- $\kappa \mathrm{B}$ signal pathway intervention group, termed the PDTC+LPS group, was treated with $20 \mathrm{mmol} / 1$ PDTC for $1 \mathrm{~h}$ prior to the administration of $500 \mathrm{ng} / \mathrm{ml} \mathrm{LPS}$. $\mathrm{SiHa}$ cells in the logarithmic growth phase were used in all experiments.

MTT assay. Cells $\left(1 \times 10^{4}\right)$ were plated into 96-well culture plates with $100 \mu 1 \mathrm{MEM}$ and each group was allocated 5 wells. During the logarithmic growth phase, treatments were added to each group and culture was continued for 1-4 days. Following growth of adherent cells, $10 \mu 1 \mathrm{MTT}(10 \mathrm{mg} / \mathrm{ml})$ was added at 0, 24, 48 and $72 \mathrm{~h}$. After adding MTT, cells continued to be cultured for another $4 \mathrm{~h}$ and then MTT activity was measured. Dimethyl sulfoxide (DMSO; $200 \mu \mathrm{l}$ ) was added to each well following removal of the cell culture medium. Blank wells were used for zero adjustment following agitation of the plates for $10 \mathrm{~min}$. Optical density (OD) values were measured for all groups at a wavelength of $570 \mathrm{~nm}$, using a microplate reader. Experiments were repeated 3 times. Cell growth inhibition curves were constructed; incubation time was plotted on the $\mathrm{x}$-axis and OD values were plotted on the $\mathrm{y}$-axis.

Soft agar colony forming experiment. Modified Thayer Martin (MTM) culture medium $(6 \mathrm{ml})$ was combined with an equal volume of $1 \%$ low melting agarose. A $0.6 \%$ bottom agar was prepared, and $4 \mathrm{ml}$ was spread over each $60 \mathrm{~mm}$ diameter plate and incubated at $4^{\circ} \mathrm{C}$ for $10 \mathrm{~min}$. Following coagulation of the bottom agar, the MTM-agarose mixture and 1,000 cells $/ \mathrm{ml}$ single cell suspensions in each group after treatments were rapidly and thoroughly mixed, and $1 \mathrm{ml}$ mixture was spread on the bottom agar. Following solidification at room temperature, culture was continued for 14 days in a $37^{\circ} \mathrm{C}$ incubator with $5 \% \mathrm{CO}_{2}$. Cell growth was subsequently observed and colony forming cells in each culture dish were counted. Each visible cell cluster ( $>500$ cells) was counted as one colony.

Verification of HIF-1 $\alpha$ expression via immunocytochemistry. Cells were treated as previously described. PBS was used instead of the primary antibody as a negative control. Following treatments, cells were washed with $0.01 \mathrm{~mol} / 1 \mathrm{PBS}$ three times, fixed with $4 \%$ paraformaldehyde at room temperature for $10 \mathrm{~min}$, and washed three times with $0.01 \mathrm{~mol} / \mathrm{l} \mathrm{PBS}$. Cells were treated with $3 \% \mathrm{H}_{2} \mathrm{O}_{2}$ for 20 min and blocked with 10\% blocking serum (AR0009; Boster Biological Technology, Pleasanton, CA, USA) for $30 \mathrm{~min}$ at room temperature. Subsequently, rabbit anti-human HIF-1 $\alpha$ antibody (1:200) was added and cells were incubated at $4^{\circ} \mathrm{C}$ overnight. Following washing with PBS three times, HRP-labeled goat anti-rabbit antibody (1:300) was added and the plate was incubated at $37^{\circ} \mathrm{C}$ for $1 \mathrm{~h}$. The plates were stained using the immunohistochemistry DAB kit and observed under a fluorescence microscope with magnification $\mathrm{x} 200$.

Western blot analysis of HIF-1 $\alpha$ expression. Cells were grouped and treated as described above and were harvested for protein extraction using a RIPA lysis solution (Beyotime Institute of Biotechnology), quantified using the bicinchoninic acid method, separated by $8 \%$ SDS-PAGE and transferred to polyvinylidene fluoride membranes. The mass of protein loaded per lane was $30 \mu \mathrm{g}$. Membranes were blocked with 5\% skimmed milk for $1 \mathrm{~h}$ at room temperature. Rabbit polyclonal anti-HIF-1 $\alpha(1: 1,000)$ and anti- $\beta$-actin $(1: 1,000)$ were added and incubated at $4{ }^{\circ} \mathrm{C}$ overnight. Subsequently, HRP-labeled goat anti-rabbit $\mathrm{IgG}$ (1:300) was added and membranes were incubated at $37^{\circ} \mathrm{C}$ for $1 \mathrm{~h}$. The results were observed by an Odyssey infrared imaging system (LI-COR). Target protein expression was quantified by image J (k 1.45; National Institutes of Health, Bethesda, MD, USA) as gray values of the target protein $/ \beta$-actin protein. The experiment was repeated three times.

ROS measurement with dichloro-dihydro-fluorescein diacetate (DCFH-DA). ROS levels were measured using an intracellular peroxide-sensitive fluorescent DCFH-DA probe. SiHa cells were seeded on 96-well plates with $100 \mu \mathrm{l}$ culture medium, and cells were treated as described. ROS was measured at 0, 12, 24,36 and $48 \mathrm{~h}$. Inoculated cells were washed twice with Earle's Balanced Salt Solution (Thermo Fisher scientific, Inc.) and incubated with $25 \mu \mathrm{M}$ DCFH-DA probe at $37^{\circ} \mathrm{C}$ for $30 \mathrm{~min}$, and washed twice with Earle's Balanced Salt Solution. Fluorescence intensity was immediately measured at a wavelength of (excitation, $485 \mathrm{~nm}$; emission, $520 \mathrm{~nm}$ ) using a spectrofluorometer (FLUOstar Optima Microplate Reader; BMG Labtech GmbH, Ortenberg, Germany).

NADPH oxidase activity. SiHa cells were seeded on 96-well plates with $100 \mu \mathrm{l}$ MEM and treated as described above. In each 
group NADPH was assayed at $0,12,24,36$ and $48 \mathrm{~h}$ following treatments as described in the section 'Treatment groups'. At each time point, cells were collected using $4^{\circ} \mathrm{C}$ cold fresh PBS using a cell scraper. The cell suspension was centrifuged at $2,500 \mathrm{x} \mathrm{g}$ at $4^{\circ} \mathrm{C}$ for $5 \mathrm{~min}$. Cells were harvested for protein extraction using a RIPA lysis solution (Beyotime Institute of Biotechnology) and then were taken for protein quantification as described. Subsequently, $50 \mu 1$ cellular protein, $5 \mu 1$ DMSO, $5 \mu \mathrm{mol} / 1$ lucigenin and $50 \mathrm{~mm} / 1$ Tiron (172553; Sigma-Aldrich; Merck KGaA) were added to 96-well plates in the dark. A total of $100 \mathrm{~mol} / \mathrm{l} \mathrm{NADPH}$ was added to initiate the reaction. NADPH oxidase activity was measured using a chemiluminescence detector and expressed as relative light units/mg protein.

Cell immunofluorescence staining. Cells were treated as described and plated on $5 \times 5 \mathrm{~mm}$ slides in $35 \mathrm{~mm}$ diameter culture dishes. When integration reached $60 \%$ confluency, the medium was removed by suction, and slides were washed with PBS and fixed with $1 \mathrm{ml} 4 \%$ polyformaldehyde for $20 \mathrm{~min}$ in the room temperature. Cells were treated with $0.5 \%$ TritonX-100 for 20 min and blocked with 5\% FBS at room temperature for 60 min. Rabbit anti human HIF-1 $\alpha$ (1:100) and mouse anti-human TLR4 (1:100) monoclonal antibodies were added and incubated overnight at $4^{\circ} \mathrm{C}$. The following day, DyLight 594-labeled goat anti-mouse IgG (1:40) and DyLight 488-labeled goat anti-rabbit $\operatorname{IgG}(1: 30)$ were added and the slides were incubated at $37^{\circ} \mathrm{C}$ for $2 \mathrm{~h}$. Nuclei were stained with DAPI (C1002; Beyotime Institute of Biotechnology). Quenching was achieved using an anti-fluorescence quenching agent and a fluorescent microscope (magnification, x200) was used to observe and capture images.

Statistical analysis. Data were analyzed using SPSS software (version 13.0; SPSS, Inc., Chicago, IL, USA). Data are presented as the mean \pm standard deviation for the indicated replicates ( $\mathrm{N}=3$ for each experiment) and $\mathrm{P}<0.05$ was considered to indicate a statistically significant difference. Comparisons of two sample means were performed using a 2-sample Student's t-test. Differences among three or more groups were evaluated using one-way analysis of variance, followed by LSD post hoc test.

\section{Results}

Cell growth. An MTT assay was used to measure cell growth (Fig. 1). Cell growth increased in the LPS group compared with the control group $(\mathrm{P}<0.01)$, although no significant difference was observed between the LPS+PDTC and control groups. Cell growth decreased in all other treatment other groups compared with the control group (all $\mathrm{P}<0.01$ ). Compared with the LPS group, cell activity was reduced in the PDTC+LPS group $(\mathrm{P}<0.05)$, and the ST2825+LPS, siTLR4+LPS and $\mathrm{M} \beta C D+L P S$ groups (all $\mathrm{P}<0.01$ ). Cell growth increased in the PDTC+LPS group compared with the ST2825+LPS, siTLR4+LPS and $\mathrm{M} \beta \mathrm{CD}+\mathrm{LPS}$ groups (all $\mathrm{P}<0.01$ ). Cell growth inhibition was time-dependent, as all significant differences were observed 4 days following treatment. LPS stimulated cervical cancer cell growth. This growth was reduced following inhibition of TLR4 and MyD88 signaling,

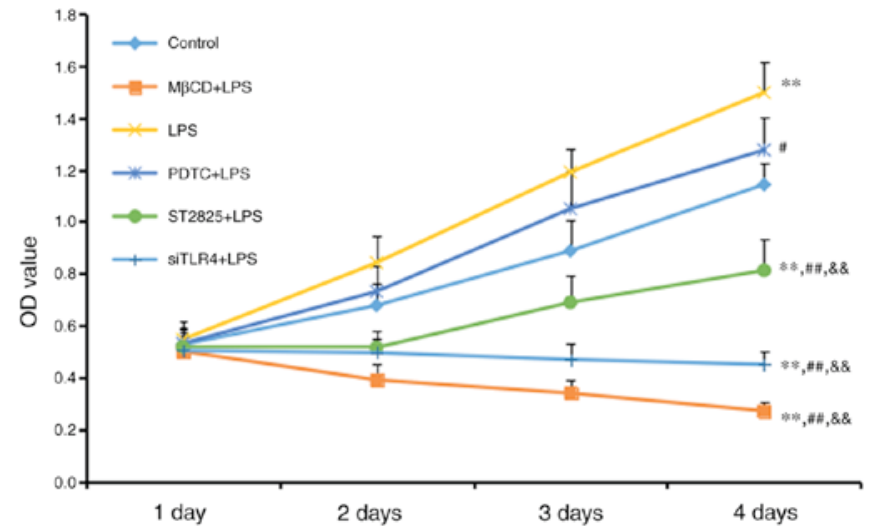

Figure 1. An MTT assay was used to measure cell growth in the groups following 1,2, 3 and 4 days of treatment. Data are presented as the mean \pm standard deviation $(\mathrm{n}=3)$. ${ }^{* *} \mathrm{P}<0.01$ vs. the control group; ${ }^{\#} \mathrm{P}<0.05$, ${ }^{\# \#} \mathrm{P}<0.01$, vs. the LPS group; ${ }^{\&} \mathrm{P}<0.01$ vs. the PDTC+LPS group. LPS, lipopolysaccharide; si, small interfering RNA; TLR4, Toll-like receptor 4; M $\beta C D$, methyl- $\beta$-cyclodextrin; PDTC, ammonium pyrrolidinedithiocarbamate.

and reduced lipid raft functionality. Inhibition of NF- $\mathrm{B}$ signaling additionally reduced $\mathrm{SiHa}$ cell growth compared with the LPS group, although this inhibition was decreased compared with the effect included by inhibition of TLR4 and MyD88 signaling, and reduced lipid raft functionality.

Colony forming experiment. Colony formation was assessed in SiHa cells in soft agar following 2 weeks of culture. Visible cell clusters ( $>500$ cells) were counted as standard colonies. Images of colonies are presented in Fig. 2A. The LPS group produced the most colonies (Fig. 2B). Compared with controls, treatment with LPS significantly promoted cell growth $(\mathrm{P}<0.01)$, while LPS+ST2825, siTLR4 and M $\beta C D$ inhibited cell growth. Compared with the LPS group, PDTC+LPS $(\mathrm{P}<0.05)$ and LPS co-administered with ST2825, siTLR4 and $\mathrm{M} \beta C D$ (all $\mathrm{P}<0.01$ ) inhibited colony formation. Compared with the PDTC+LPS group, colony numbers decreased following treatment with ST2825+LPS $(\mathrm{P}<0.05)$ and LPS co-treatment with siTLR4 and M $\beta C D(P<0.01)$. Therefore, LPS stimulated cervical cancer cell growth. Inhibition of TLR4, MyD88, and $\mathrm{NF}-\kappa \mathrm{B}$ signaling and lipid raft functionality inhibited growth of cervical cancer cells treated with LPS. However, inhibition of TLR4 and MyD88 signaling, and disruption of lipid raft functionality, demonstrated more significant effects compared with inhibition of NF- $\mathrm{KB}$.

Western blot analysis of HIF-1 $\alpha$ expression. HIF-1 $\alpha$ expression was assayed in $\mathrm{SiHa}$ cells for $24 \mathrm{~h}$ and immunohistochemical data were collected (Fig. 3A). Western blotting images are presented in Fig. 3B. Compared with the control group, HIF-1 $\alpha$ expression increased following treatment with LPS $(\mathrm{P}<0.01)$ and decreased when LPS was co-administered with ST2825 $(\mathrm{P}<0.05)$, siTLR4 and M $\beta C D$ (both $\mathrm{P}<0.01)$. Compared with the LPS treatment, HIF-1 $\alpha$ expression decreased when LPS was administered following pre-treatment with PDTC $(\mathrm{P}<0.05)$, ST2825, siTLR4 and $\mathrm{M} \beta \mathrm{CD}(\mathrm{P}<0.01) . \mathrm{HIF}-1 \alpha$ expression was lowest in the M $\beta C D+L P S$ group. Compared with the PDTC+LPS treatment group, HIF-1 $\alpha$ expression decreased in the LPS+ST2825 $(\mathrm{P}<0.05)$, siTLR4 and M $\beta C D$ 


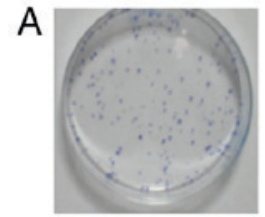

Control

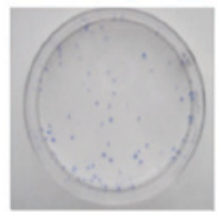

siTLR4+LPS

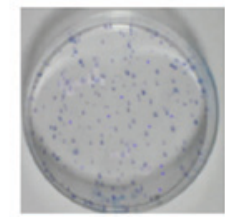

LPS

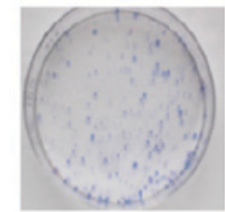

PDTC+LPS

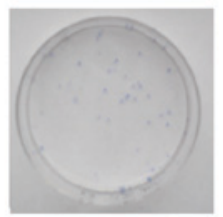

MBCD+LPS

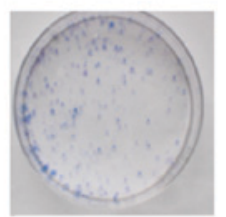

ST2825+LPS
B

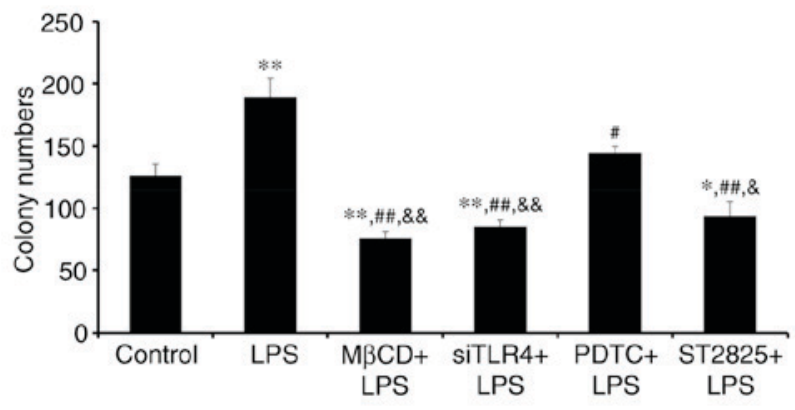

Figure 2. Soft agar colony forming experiment. (A) Images of soft agar plate colony formation for treatment groups following 2 weeks of culture. (B) Quantification of colony numbers. Data are presented as the mean \pm standard deviation $(\mathrm{n}=3)$. ${ }^{*} \mathrm{P}<0.05$ and ${ }^{* * *} \mathrm{P}<0.01$ vs. the control group; ${ }^{\#} \mathrm{P}<0.05,{ }^{\# \#} \mathrm{P}<0.01$ vs. the LPS group; ${ }^{\&} \mathrm{P}<0.05$ and ${ }^{\& \&} \mathrm{P}<0.01$ vs. the PDTC+LPS group. LPS, lipopolysaccharide; si, small interfering RNA; TLR4, Toll-like receptor 4; M $\beta C D$, methyl- $\beta$-cyclodextrin; PDTC, ammonium pyrrolidinedithiocarbamate.

(both $\mathrm{P}<0.01$ ) treatment groups. Therefore, the above data suggested that the stimulation of TLR4 signaling induced the expression of HIF-1 $\alpha$ and the inhibition of TLR4 and MyD88 signaling, and disruption of lipid raft functionality inhibited HIF-1 $\alpha$ expression. Inhibition of the NF- $\kappa \mathrm{B}$ signaling pathway decreased HIF-1 $\alpha$ expression, although not to the same extent as inhibition of TLR4 and MyD88 signaling and lipid raft disruption.

Lucigenin luminescent assay for NADPH oxidase activity. NADPH oxidase activity was determined in SiHa cells, treated as previously described, at $0,12,24,36$, and $48 \mathrm{~h}$ (Fig. 4). NADPH oxidase activity increased over time in all groups. Compared with the control group, treatment with LPS and PDTC+LPS enhanced NADPH oxidase activity at $24 \mathrm{~h}$ $(\mathrm{P}<0.05)$. NADPH oxidase activity decreased when LPS was administered with ST2825, siTLR4 and M $3 C D$. Compared with the LPS groups, NADPH oxidase activity decreased when LPS was co-administered with ST2825, siTLR4 and $M \beta C D$, although no significant difference was observed in the PDTC+LPS group. Compared with the PDTC+LPS group, NADPH oxidase activity in LPS+ST2825, siTLR4 and M $\beta C D$ decreased. Therefore, stimulation of TLR4 signaling increased NADPH oxidase activity and inhibition of lipid raft functionality, and TLR4 and MyD88 signaling inhibited NADPH oxidase activity. However, inhibition of NF- $\kappa \mathrm{B}$ signaling activation did not alter NADPH oxidase activity, compared with the levels observed in the LPS group.

DCFH-DA detection of ROS activity. ROS activity alterations in $\mathrm{SiHa}$ cells treated with various interventions were assayed using a DCFH-DA probe, following $0,12,24,36$, and $48 \mathrm{~h}$ of treatment (Fig. 5). ROS content in the M $\beta C D+L P S$ group decreased over time and there was an initial decrease followed by a gradual increase in the siTLR4+LPS group. ROS in the remaining groups increased over time. Compared with the control group, ROS expression was enhanced following treatment with LPS and PDTC+LPS, and was decreased when LPS was administered following pretreatment with ST2825, siTLR4 and $\mathrm{M} \beta \mathrm{CD}$ (all $\mathrm{P}<0.05$ ). Compared with the LPS group, ROS activity decreased in the LPS+ST2825, siTLR4 and M $\beta C D$ groups, and was not significantly different compared with the PDTC+LPS treatment. Compared with the PDTC+LPS treatment, ROS in SiHa cells decreased in the LPS+ST2825, siTLR4 and $\mathrm{M} \beta C D$ groups (all $\mathrm{P}<0.01$ ). Therefore, stimulation of TLR4 signaling promoted the generation of ROS in cervical cancer cells, and the inhibition of lipid raft functionality, and the TLR4 and MyD88 signaling pathways, inhibited ROS production. Inhibition of NF- $\kappa \mathrm{B}$ signaling exerted no significant effect on intracellular ROS levels compared with the LPS group.

Fluorescence microscopy detection of the co-localization of TLR4 and HIF-1 $\alpha$. TLR4 and HIF-1 $\alpha$ were detected by immunofluoresce following treatment as described in the Treatment groups for $24 \mathrm{~h}$. Localization of TLR 4 and HIF- $1 \alpha$ in cells was investigated using fluorescent microscopy, and TLR4 and HIF-1 $\alpha$ were labeled using immunofluorescent staining (Fig. 6). HIF-1 $\alpha$ expression was labeled in green and TLR4 expression was labeled in red. TLR4 localized to the cell surface but HIF-1 $\alpha$ primarily localized to the cytoplasm. TLR4 was co-localized with HIF-1 $\alpha$ in cervical cancer cells.

\section{Discussion}

The TLR4 receptor is expressed on the surface of a number of immune cells and serves a role in innate immunity against bacterial infection. The activation of TLR4 signaling leads to secretion of cytokines and regulate adaptive immune responses. TLR4 is expressed on multiple tumor cell surfaces, including in lung, breast and cervical cancer $(11,30,31)$. Activation of TLR4 signaling on tumor surfaces may promote proliferation and inhibit apoptosis in tumor cells and, unlike activation on immune cell surfaces, this may promote tumor growth (32-34). A previous study indicated that the elevated expression of TLR4 in cervical cancer cells was positively associated with increased HIF-1 $\alpha$ activity and this is implicated in cervical cancer growth (23).

HIF- $1 \alpha$ is a marker of malignant prognosis and excessive activation of HIF- $1 \alpha$ promotes the growth, invasion and metastasis of tumor cells, and induces tumor cell resistance to radiotherapy and chemotherapy (35). Excessive activation 


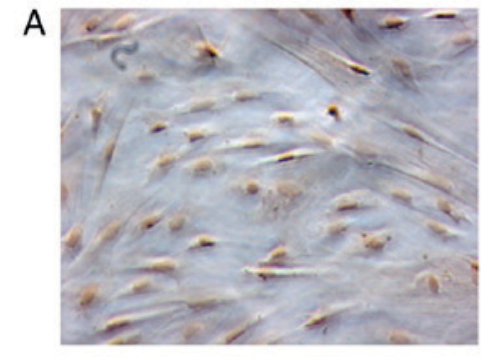

Control

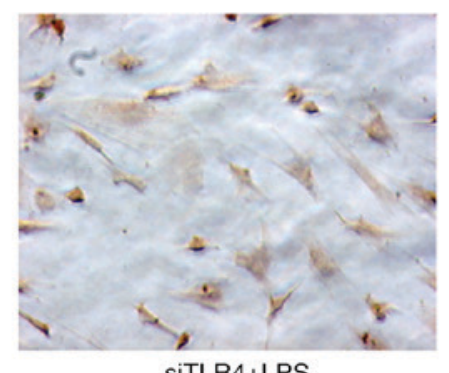

SiTLR4+LPS

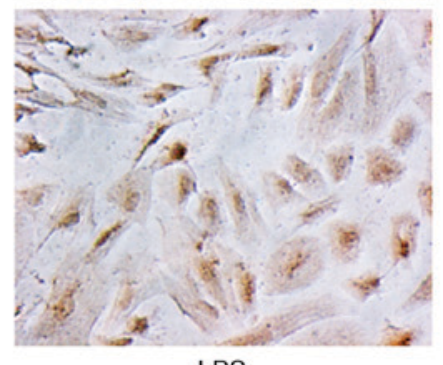

LPS

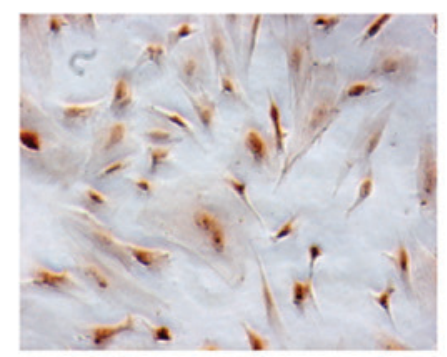

PDTC+LPS

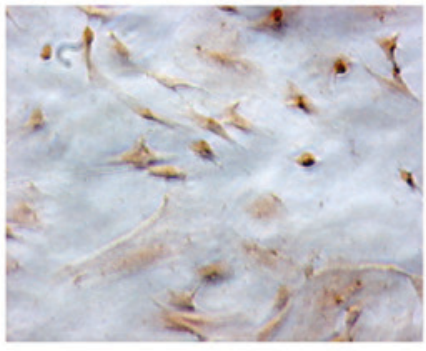

$\mathrm{MBCD}+\mathrm{LPS}$

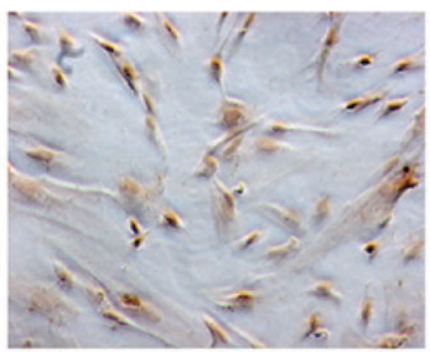

ST2825+LPS

B

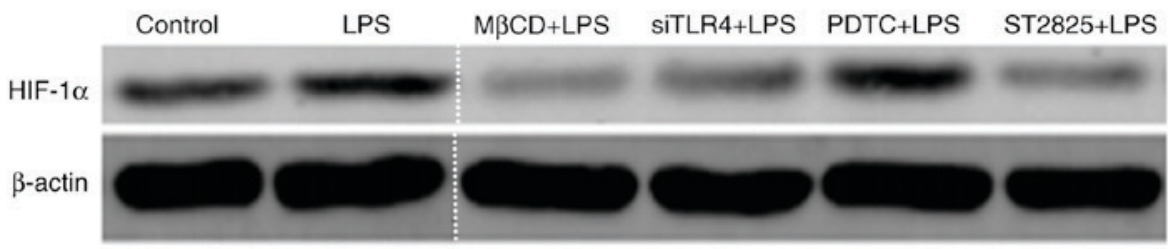

C

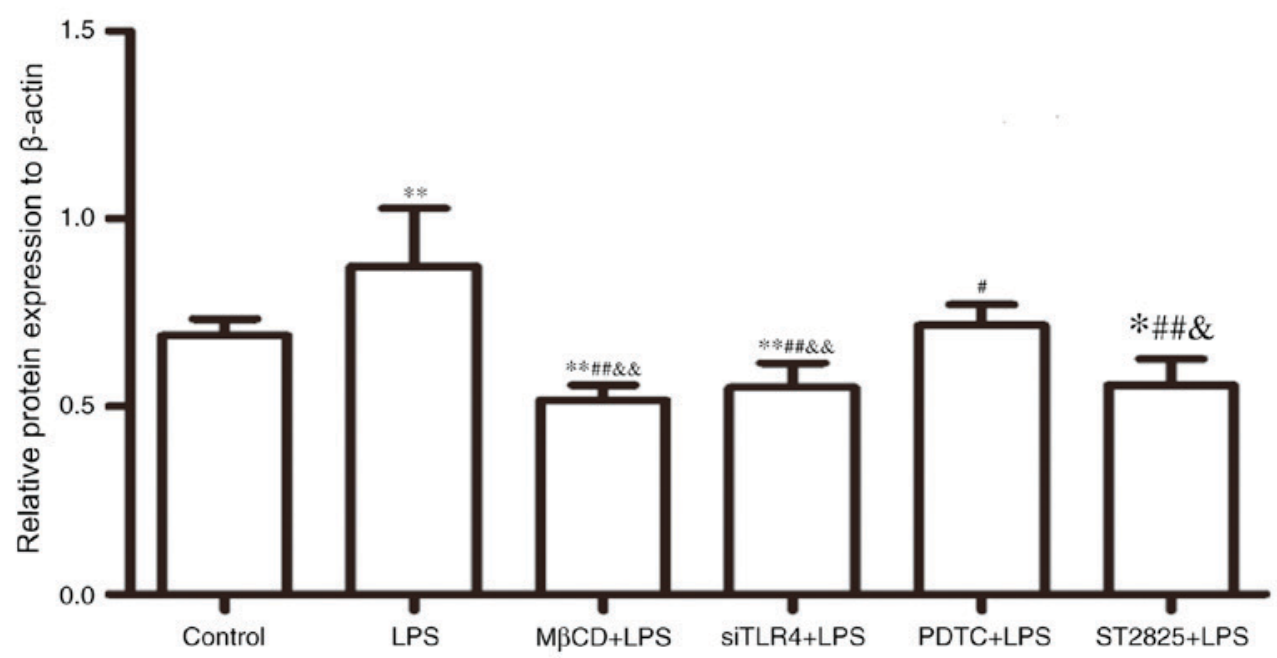

Figure 3. HIF-1 $\alpha$ expression levels. (A) Immunocytochemistry images (magnification, x100). Positive cells were stained brown-yellow. (B) Western blot analysis of HIF-1 $\alpha$ expression levels. (C) Statistical analysis of western blotting. The gel was cut to improve the clarity of the figure, as shown by a dotted line. Data are presented as the mean \pm standard deviation $(\mathrm{n}=3) .{ }^{*} \mathrm{P}<0.05$ and ${ }^{* * *} \mathrm{P}<0.01$ vs. the control group; ${ }^{\#} \mathrm{P}<0.05$, ${ }^{\# \prime} \mathrm{P}<0.01$ vs. the LPS group; ${ }^{\circledR} \mathrm{P}<0.05$ and ${ }^{\&} \mathrm{P}<0.01$ vs. the PDTC+LPS group. LPS, lipopolysaccharide; si, small interfering RNA; TLR4, Toll-like receptor 4; M $\beta C D$, methyl- $\beta$-cyclodextrin; PDTC, ammonium pyrrolidinedithiocarbamate.

of HIF-1 $\alpha$ is associated with inhibition of prolyl hydroxylase enzyme (PHD) activity, which indicates that ROS may inhibit PHDs, and prevent the degradation and enhance the stability of HIF-1 $\alpha$ (36). A previous study demonstrated that increased levels of ROS maintain elevated HIF-1 $\alpha$ activity in cervical cancer cells during hypoxia (26). However, the role of elevated expression of HIF-1 $\alpha$ in non-hypoxic areas of cervical cancer remains to be elucidated.

TLR4 signaling balances the activation of NF- $\kappa B$ signaling, which inhibits HIF-1 $\alpha$ degradation to maintain its activity (37-39). The present study and previous studies demonstrated that activation of the TLR4 signaling pathway is associated with lipid rafts $(14,26)$, which are microdomains located within the cell membrane that are rich in cholesterol, sphingolipids and the liquid ordered phase of receptors. Lipid rafts are dynamic functional platforms through which external signals are transmitted via receptors to the cells (40). Lipid rafts provide activation and transduction platform for the initiation of the TLR4 signaling pathway, which may not be activated when expression of proteins such as (such as CD14) that form the lipid structure or fluidity is inhibited. Lipid rafts are not only enriched with sphingolipids and cholesterol 


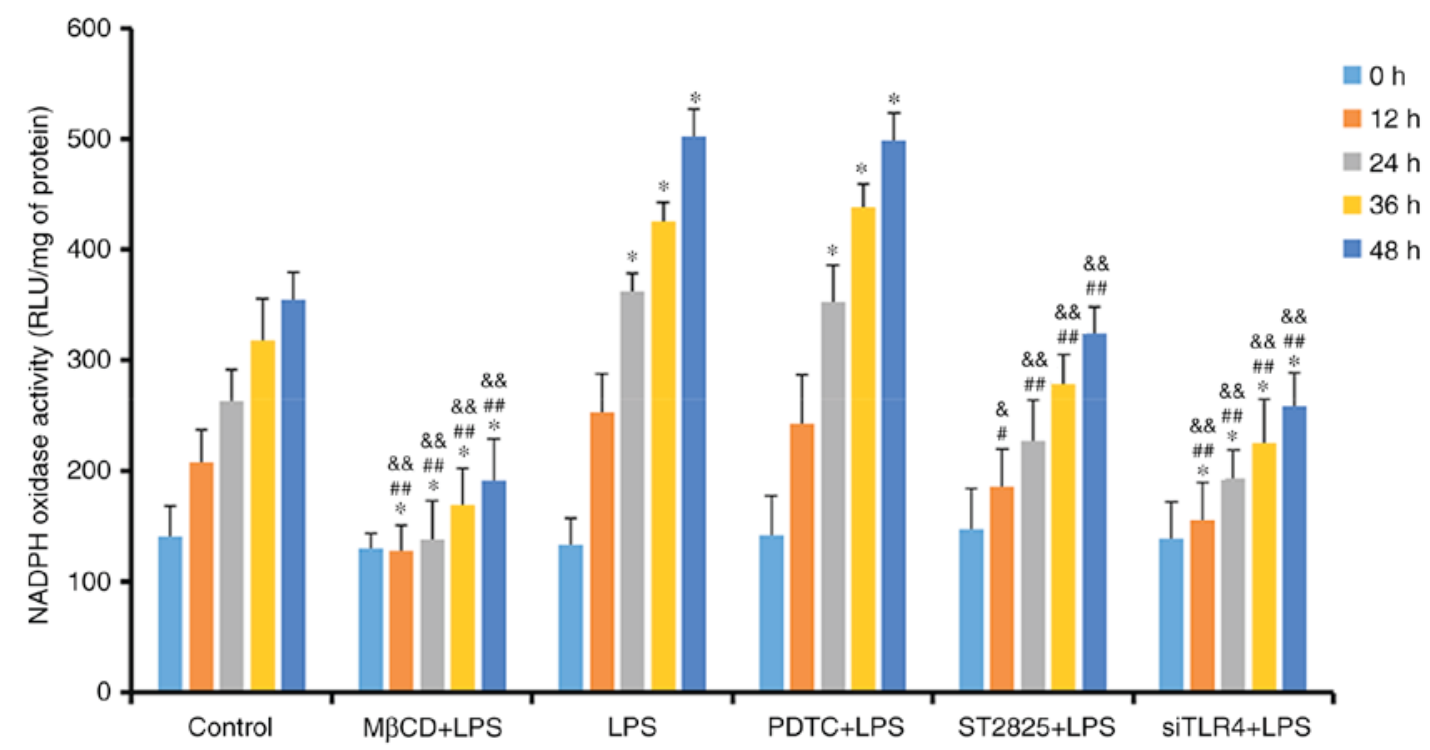

Figure 4. Detection of NADPH oxidase activity in treatment groups at $0,12,24,36$ and $48 \mathrm{~h}$. ${ }^{*} \mathrm{P}<0.05$ and ${ }^{* *} \mathrm{P}<0.01$ vs. the control group at $0,12,24,36$ and $48 \mathrm{~h}$. ${ }^{\#} \mathrm{P}<0.05,{ }^{\# \#} \mathrm{P}<0.01$ vs. the LPS group at $0,12,24,36$ and $48 \mathrm{~h} .{ }^{\text {\& }} \mathrm{P}<0.05$ and ${ }^{\& \&} \mathrm{P}<0.01$ vs. the PDTC+LPS group at $0,12,24,36$ and 48 h. LPS, lipopolysaccharide; si, small interfering RNA; TLR4, Toll-like receptor 4; M $\beta C D$, methyl- $\beta$-cyclodextrin; PDTC, ammonium pyrrolidinedithiocarbamate; nicotinamide-adenine dinucleotide phosphate; NADPH, nicotinamide-adenine dinucleotide phosphate; RLU, relative light units.

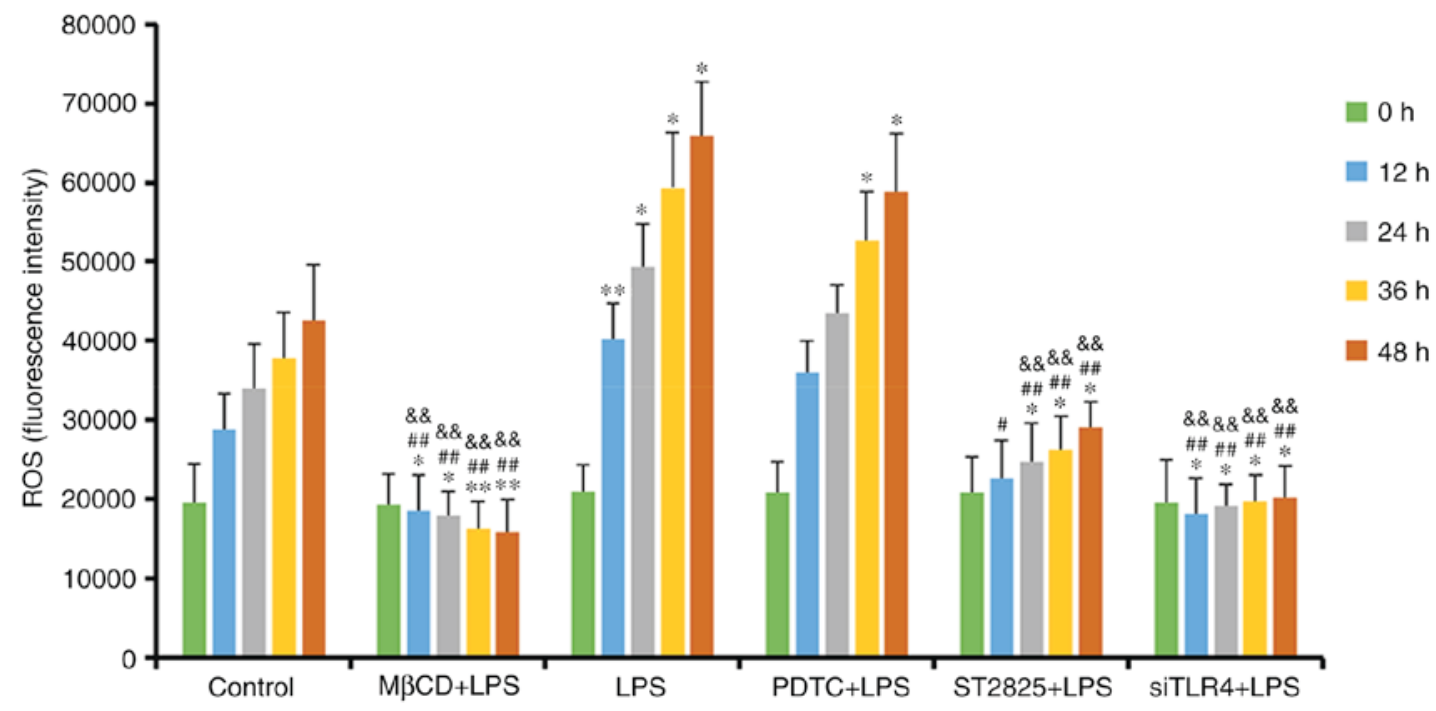

Figure 5. ROS fluorescence intensity of each group detected at $0,12,24,36$ and $48 \mathrm{~h}$. ${ }^{*} \mathrm{P}<0.05$ and ${ }^{* *} \mathrm{P}<0.01$ vs. the control group at $0,12,24,36$ and $48 \mathrm{~h}$. ${ }^{\# \#} \mathrm{P}<0.01$, vs. the LPS group at $0,12,24,36$ and $48 \mathrm{~h}$. \&\& $\mathrm{P}<0.01$ vs. the PDTC+LPS group at $0,12,24,36$ and $48 \mathrm{~h}$. LPS, lipopolysaccharide; si, small interfering RNA; TLR4, Toll-like receptor 4; M $\beta C D$, methyl- $\beta$-cyclodextrin; PDTC, ammonium pyrrolidinedithiocarbamate; ROS, reactive oxygen species.

that float within the phospholipid bilayer cell membrane but also contain many signaling proteins. These rafts can serve as platforms for the formation of multicomponent complexes. Many transmembrane receptors are recruited into lipid raft upon stimulation and resulting in downstream signaling (41). Therefore, a TLR4 signaling effect is more apparent following stimulation of lipid raft function (42). LPS binds to the complex of CD14 and lipopolysaccharide binding protein (LBP), forming a LPS-LBP-mCD14 complex that can activate the TLR4-MD2-MyD88 recognition complex or the TLR4-TRAM-TRIF complex on target cells. Then the complexes can activate $\mathrm{NF}-\kappa \mathrm{B}$ or the interferon regulatory factor 3 pathway to cause secretion of tumor necrosis factor- $\alpha$, interleukin-2 (IL-2), IL-6, and interferon- $\gamma$ (23). In addition, lipid rafts aid in promoting and maintaining ROS levels derived from NADPH oxidase in cells (43). ROS levels generated by NADPH oxidase decrease following lipid raft damage, and aggregation of lipid rafts on cell membranes may modify NADPH oxidase subunits, causing activation of NADPH oxidase and an increase in intracellular ROS levels (44-46). However, the mechanism underlying the lipid raft-mediated contribution to cervical cancer development, by maintaining increased HIF- $1 \alpha$ activity mediated by TLR4, remains to be elucidated.

Therefore, the authors of the present study hypothesized that TLR4 combined with its ligands may trigger the molecular flow of lipid rafts and induce alterations in their spatial configuration. Conformational alterations could provide 
TLR4
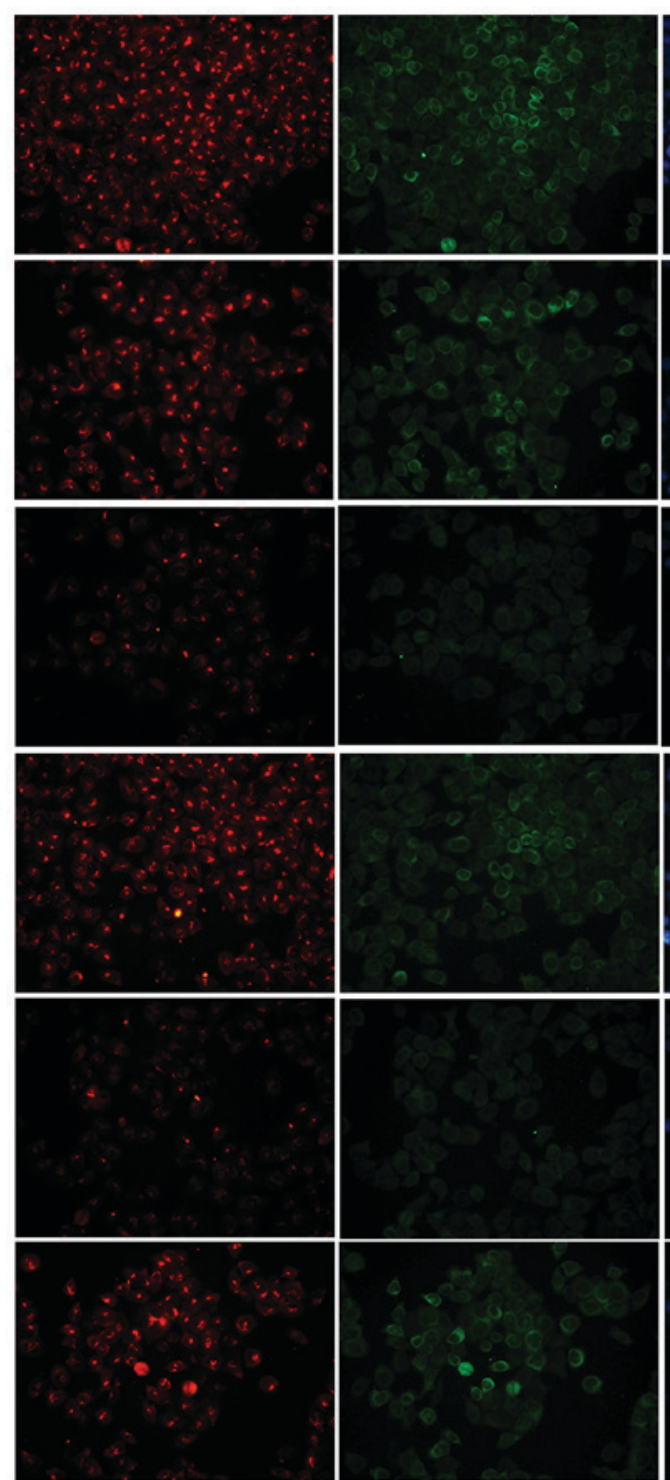

DAPI
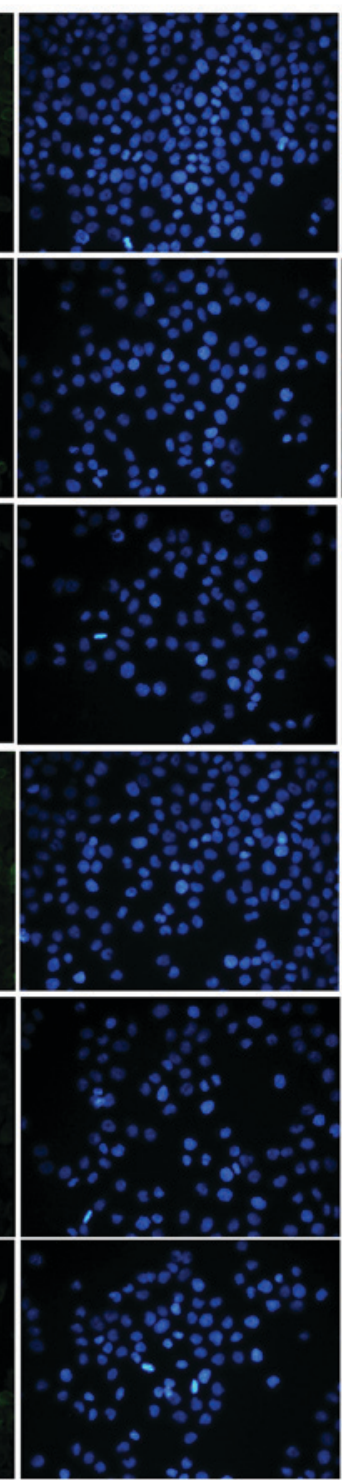
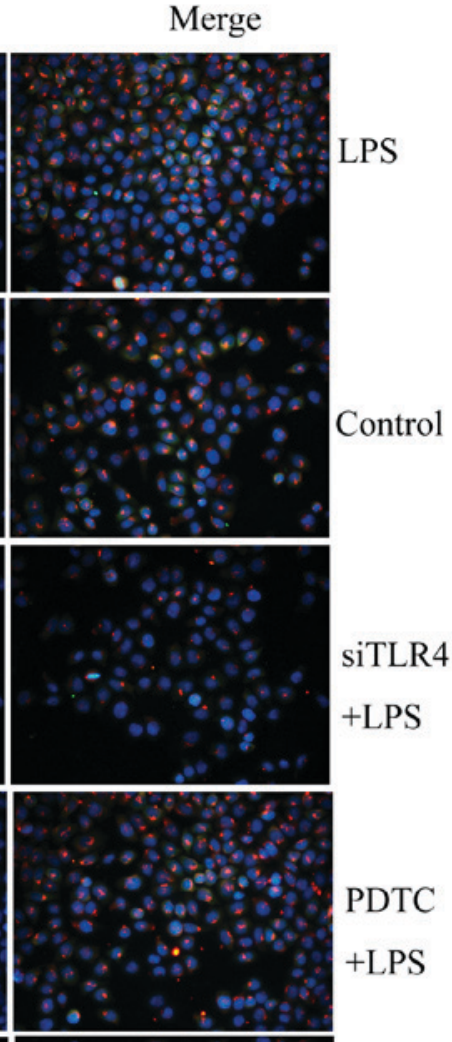

PDTC

+LPS

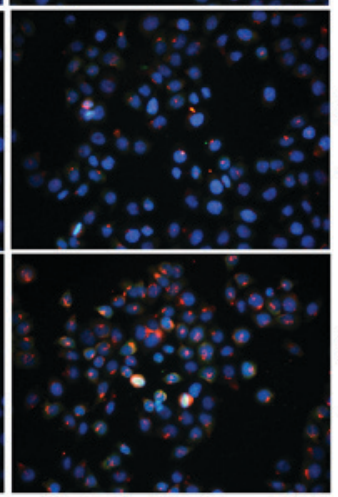

$\mathrm{M} \beta \mathrm{CD}$

+ LPS

ST2825

+ LPS

Figure 6. The expression and co-localization of TLR4 and HIF-1 $\alpha$ detected by immunofluorescence staining. Green, HIF-1 $\alpha$ expression; red, TLR4 expression; blue, nuclei. LPS, lipopolysaccharide; si, small interfering RNA; TLR4, Toll-like receptor 4; M $\beta C D$, methyl- $\beta$-cyclodextrin; PDTC, ammonium pyrrolidinedithiocarbamate.

conditions for the aggregation of NADPH oxidase subunits to the lipid rafts and then activating redox signals, inhibiting HIF-1 $\alpha$ degradation and increasing its expression.

The present study investigated the proliferation and cloning of SiHa cells, and alterations in ROS levels, NADPH oxidase activity and HIF-1 $\alpha$ expression following inhibition or activation of TLR4, MyD88 and NF- $\mathrm{B}$ signaling, and inhibition of lipid raft functionality. Compared with the control group, LPS stimulated TLR4 signaling which promoted cervical cancer cell growth and increased HIF-1 $\alpha$ expression, NADPH oxidase activity and ROS content. Silencing of TLR4 expression using siTLR4 inhibited the growth of cervical cancer cells and reduced HIF-1 $\alpha$ expression, NADPH oxidase activity and ROS content. Therefore, TLR4 may be hypothesized to be associated with cervical cancer initiation, and the development and maintenance of elevated HIF-1 $\alpha$ expression in cervical cancer cells. The underlying mechanism may be associated with ROS produced by NADPH oxidase. Compared with TLR4 signal activation alone, inhibition of lipid raft functionality following TLR4 activation significantly inhibited cervical cancer growth and HIF-1 $\alpha$ expression levels, NADPH oxidase activity and ROS levels. Therefore, lipid rafts serve a role in the activation of TLR4 signaling and ROS content by altering NADPH oxidase activity. Compared with TLR4 signal activation alone (LPS group), inhibition of MyD88 and NF- $\kappa \mathrm{B}$ signaling following TLR4 activation inhibited $\mathrm{SiHa}$ cell growth and reduced HIF-1 $\alpha$ activity. Inhibition of $N F-\kappa B$ signaling did not exhibit the same effect as TLR4 signaling with respect to inhibition of $\mathrm{SiHa}$ cell growth and the reduction of HIF-1 $\alpha$ activity. NADPH oxidase activity and ROS content decreased following inhibition of TLR4 signaling, but NADPH oxidase activity and ROS content were not significantly altered following inhibition of $\mathrm{NF}-\kappa \mathrm{B}$ signaling, compared with the LPS group. TLR4 binds LPS via auxiliary factors lymphocyte antigen 69 and CD14, and intracellularly transduces signals by activating downstream MyD88 signal transduction molecules, 
eventually leading to the activation of $\mathrm{NF}-\kappa \mathrm{B}$ signaling (47). MyD88 is an upstream signal of $\mathrm{NF}-\kappa \mathrm{B}(48-50)$ which may be associated with the activation of NADPH oxidase activity independently of $\mathrm{NF}-\kappa \mathrm{B}$ signaling and may be used to measure the activity of TLR4. From the present results, it was demonstrated that $\mathrm{NF}-\kappa \mathrm{B}$ signaling may be involved in cervical cancer growth and may increase HIF-1 $\alpha$ activity via other mechanisms, independently of NADPH oxidase.

Compared with inhibition of $\mathrm{NF}-\kappa \mathrm{B}$ signaling, inhibition of lipid raft functionality following TLR4 signaling activation by LPS significantly inhibited cervical cancer cell growth and reduced intracellular HIF-1 $\alpha$ expression, NADPH oxidase activity and ROS levels. Therefore, based on the results of the present study, it may be hypothesized that TLR4 primarily increases NADPH oxidase activity via the lipid raft-associated pathway rather than the NF- $\kappa \mathrm{B}$ signaling pathway and, subsequently, TLR4 is involved in the maintenance of the elevated expression of HIF-1 $\alpha$, which promotes cervical cancer. TLR4 and HIF-1 $\alpha$ were immunofluorescently labeled in the present study and their cellular locations were identified. TLR4 was located on the cell surface, and HIF-1 $\alpha$ was localized to the cytoplasm. TLR4 content was proportional the levels of HIF-1 $\alpha$. Inhibition of TLR4 signaling and lipid raft functionality inhibited HIF-1 $\alpha$ expression, suggesting that TLR4 and lipid rafts aid in maintaining elevated HIF- $1 \alpha$ activity in cervical cancer cells.

In conclusion, TLR4 signaling, lipid rafts and $\mathrm{NF}-\kappa \mathrm{B}$ signaling contribute to cervical cancer. TLR4 signaling may trigger ROS production by lipid rafts/NADPH oxidase-dependent mechanisms to maintain elevated HIF-1 $\alpha$ expression. However, the results of the present study suggested that this may be a separate process from the activation of $\mathrm{NF}-\kappa \mathrm{B}$, which is downstream of TLR4 signaling. Stimulation of TLR4 may increase HIF-1 $\alpha$ expression, although this effect was more evidently promoted by the TLR4/lipid rafts/NADPH oxidase pathway compared with the TLR4-NF- $\kappa \mathrm{B}$ signaling pathway. $\mathrm{NF}-\kappa \mathrm{B}$ signaling may promote cervical cancer through other mechanisms. The present study suggested a novel mechanism underlying elevated HIF-1 $\alpha$ expression and tumor formation. In addition, TLR4 signaling pathway intervention may regulate the lipid raft/NADPH oxidase/ROS/HIF-1 $\alpha$ signaling pathway and affect cancer. TLR4 signal transduction may be suppressed following inhibition of lipid raft function, and a TLR4 signaling pathway inhibitor or lipid raft interference may inhibit cancer growth and aid in the development of novel therapies for the treatment of cervical cancer.

\section{Acknowledgements}

The present study was supported by the Natural Science Foundation of China (grant no. 81302273) and the Science and Technology Department Support Project of Hubei Province, China (grant no. 2015BCA313).

\section{References}

1. Wei KR, Chen WQ, Zhang SW, Zheng RS, Wang YN and Liang ZH: Epidemiology of uterine corpus cancer in some cancer registering areas of China from 2003-2007. Zhonghua Fu Chan Ke Za Zhi 47: 445-451, 2012 (In Chinese).

2. Sharma N, Akhade AS and Qadri A: Src kinases central to T-cell receptor signaling regulate TLR-activated innate immune responses from human T cells. Innate Immun 22: 238-244, 2016
3. Galli R, Starace D, Busà R, Angelini DF, Paone A, De Cesaris $\mathrm{P}$, Filippini A, Sette C, Battistini L, Ziparo E and Riccioli A: TLR stimulation of prostate tumor cells induces chemokine-mediated recruitment of specific immune cell types. J Immunol 184: 6658-6669, 2010.

4. Molteni M, Marabella D, Orlandi C and Rossetti C: Melanoma cell lines are responsive in vitro to lipopolysaccharide and express TLR-4. Cancer Lett 235: 75-83, 2006.

5. MacRedmond R, Greene C, Taggart CC, McElvaney N and O'Neill S: Respiratory epithelial cells require Toll-like receptor 4 for induction of human beta-defensin 2 by lipopolysaccharide. Respir Res 6: 116, 2005.

6. Oblak A and Jerala R: Toll-like receptor 4 activation in cancer progression and therapy. Clin Dev Immunol 2011: 609579, 2011.

7. Roxburgh CS and McMillan DC: The role of the in situ local inflammatory response in predicting recurrence and survival in patients with primary operable colorectal cancer. Cancer Treat Rev 38: 451-466, 2012.

8. Woo JK, Kang JH, Jang YS, Ro S, Cho JM, Kim HM, Lee SJ and Oh SH: Evaluation of preventive and therapeutic activity of novel non-steroidal anti-inflammatory drug, CG100649, in colon cancer: Increased expression of TNF-related apoptosis-inducing ligand receptors enhance the apoptotic response to combination treatment with TRAIL. Oncol Rep 33: 1947-1955, 2015.

9. Goto Y, Arigami T, Kitago M, Nguyen SL, Narita N, Ferrone S, Ferrone S, Morton DL, Irie RF and Hoon DS: Activation of Toll-like receptors 2, 3, and 4 on human melanoma cells induces inflammatory factors. Mol Cancer Ther 7: 3642-3653, 2008.

10. Yu L and Chen S: Toll-like receptors expressed in tumor cells: Targets for therapy. Cancer Immunol Immunother 57: 1271-1278, 2008.

11. Nishimura $\mathrm{M}$ and Naito S: Tissue-specific mRNA expression profiles of human toll-like receptors and related genes. Biol Pharm Bull 28: 886-892, 2005.

12. Wang Y, Weng Y, Shi Y, Xia X, Wang S and Duan H: Expression and functional analysis of Toll-like receptor 4 in human cervical carcinoma. J Membr Biol 247: 591-599, 2014.

13. Song J, Fan HJ, Li H, Ding H, Lv Q and Hou SK: Zingerone ameliorates lipopolysaccharide-induced acute kidney injury by inhibiting Toll-like receptor 4 signaling pathway. Eur $\mathbf{J}$ Pharmacol 772: 108-114, 2016.

14. Fessler MB and Parks JS: Intracellular lipid flux and membrane microdomains as organizing principles in inflammatory cell signaling. J Immunol 187: 1529-1535, 2011.

15. Semenza GL: Targeting HIF-1 for cancer therapy. Nat Rev Cancer 3: 721-732, 2003.

16. Nishi H, Sasaki T, Nagamitsu Y, Terauchi F, Nagai T, Nagao T and Isaka K: Hypoxia inducible factor-1 mediates upregulation of urokinase-type plasminogen activator receptor gene transcription during hypoxia in cervical cancer cells. Oncol Rep 35: 992-998, 2016.

17. Myllyharju J and Koivunen P: Hypoxia-inducible factor prolyl 4-hydroxylases: Common and specific roles. Biol Chem 394: 435-448, 2013

18. Yatabe N, Kyo S, Maida Y, Nishi H, Nakamura M, Kanaya T, Tanaka M, Isaka K, Ogawa S and Inoue M: HIF-1-mediated activation of telomerase in cervical cancer cells. Oncogene 23: 3708-3715, 2004

19. Jing S, Xu Q, Jing S, Zhao Z, Zhao Z, Wu F, Liu Q, Cheng Y and Wang J: Effect of silencing HIF-1 $\alpha$ by RNA interference on adhesion and invasion of the human nasopharyngeal carcinoma cell line CNE-1. Zhonghua Er Bi Yan Hou Tou Jing Wai Ke Za Zhi 50: 929-933, 2015 (In Chinese).

20. Tong Y, Yang H, Xu X, Ruan J, Liang M, Wu J and Luo B: Effect of a hypoxic microenvironment after radiofrequency ablation on residual hepatocellular cell migration and invasion. Cancer Sci 108: 753-762, 2017.

21. Jiang JH, Wang ZR, Jiang L, Bao Y and Cheng YX: Mechanism of anti-tumor effect of HIF-lalpha silencing on cervical cancer in nude mice. Zhonghua Zhong Liu Za Zhi 31: 820-825, 2009 (In Chinese).

22. Peyssonnaux C, Cejudo-Martin P, Doedens A, Zinkernagel AS, Johnson RS and Nizet V: Cutting edge: Essential role of hypoxia inducible factor-1alpha in development of lipopolysaccharide-induced sepsis. J Immunol 178: 7516-7519, 2007.

23. Cheng YX, Hu M, Chen L, Huang JL, Xia LB, Li BS, Zhou LM and Hong L: The mechanism of lipid raft mediating chemoresistance of cervical cancer. Saudi Med J 33: 508-514, 2012.

24. Niecknig H, Tug S, Reyes BD, Kirsch M, Fandrey J and Berchner-Pfannschmidt U: Role of reactive oxygen species in the regulation of HIF-1 by prolyl hydroxylase 2 under mild hypoxia. Free Radic Res 46: 705-717, 2012. 
25. Cheng Y, Chen G, Hong L, Zhou L, Hu M, Li B, Huang J, Xia L and $\mathrm{Li} \mathrm{C}$ : How does hypoxia inducible factor- $1 \alpha$ participate in enhancing the glycolysis activity in cervical cancer? Ann Diagn Pathol 17: 305-311, 2013

26. Cheng YX, Qi XY, Huang JL, Hu M, Zhou LM, Li BS and $\mathrm{Xu} \mathrm{XX}$ : Toll-like receptor 4 signaling promotes the immunosuppressive cytokine production of human cervical cancer. Eur J Gynaecol Oncol 33: 291-294, 2012.

27. Feng Z, Wang Z, Yang M,Zhou L and Bao Y: Polysaccharopeptide exerts immunoregulatory effects via MyD88-dependent signaling pathway. Int J Biol Macromol 82: 201-207, 2015.

28. Carlson CG, Stein L, Dole E, Potter RM and Bayless D: Agents which inhibit NF- $\kappa \mathrm{B}$ signaling block spontaneous contractile activity and negatively influence survival of developing myotubes. J Cell Physiol 231: 788-797, 2016.

29. Sághy É, Szőke É, Payrits M, Helyes Z, Börzsei R, Erostyák J, Jánosi TZ, Sétáló G Jr and Szolcsányi J: Evidence for the role of lipid rafts and sphingomyelin in $\mathrm{Ca}^{2+}$-gating of Transient Receptor Potential channels in trigeminal sensory neurons and peripheral nerve terminals. Pharmacol Res 100: 101-106, 2015.

30. Zhan Z, Xie X, Cao H, Zhou X, Zhang XD, Fan H and Liu Z Autophagy facilitates TLR4- and TLR3-triggered migration and invasion of lung cancer cells through the promotion of TRAF6 ubiquitination. Autophagy 10: 257-268, 2013.

31. Yu L, Wang L, Li M, Zhong J, Wang Z and Chen S: Expression of toll-like receptor 4 is downregulated during progression of cervical neoplasia. Cancer Immunol Immunother 59: 1021-1028, 2010 .

32. Szczepanski MJ, Czystowska M, Szajnik M, Harasymczuk M, Boyiadzis M, Kruk-Zagajewska A, Szyfter W, Zeromski J and Whiteside TL: Triggering of Toll-like receptor 4 expressed on human head and neck squamous cell carcinoma promotes tumor development and protects the tumor from immune attack. Cancer Res 69: 3105-3113, 2009.

33. Huang B, Zhao J, Li H, He KL, Chen Y, Chen SH, Mayer L, Unkeless JC and Xiong H: Toll-like receptors on tumor cells facilitate evasion of immune surveillance. Cancer Res 65: 5009-5014, 2005.

34. Wang EL, Qian ZR, Nakasono M, Tanahashi T, Yoshimoto K, Bando Y, Kudo E, Shimada M and Sano T: High expression of Toll-like receptor $4 /$ myeloid differentiation factor 88 signals correlates with poor prognosis in colorectal cancer. Br J Cancer 102: 908-915, 2010.

35. Iovine B, Guardia F, Irace C and Bevilacqua MA: 1-carnosine dipeptide overcomes acquired resistance to 5 -fluorouracil in HT29 human colon cancer cells via downregulation of HIF1-alpha and induction of apoptosis. Biochimie 127: 196-204, 2016.

36. Acker T, Fandrey J and Acker H: The good, the bad and the ugly in oxygen-sensing: ROS, cytochromes and prolyl-hydroxylases. Cardiovasc Res 71: 195-207, 2006.

37. Nishi K, Oda T, Takabuchi S, Oda S, Fukuda K, Adachi T, Semenza GL, Shingu K and Hirota K: LPS induces hypoxiainducible factor 1 activation in macrophage-differentiated cells in a reactive oxygen species-dependent manner. Antioxid Redox Signal 10: 983-995, 2008.
38. Tewari R, Choudhury SR, Ghosh S, Mehta VS, Sen E. Involvement of TNF $\alpha$-induced TLR4-NF- $\mathrm{BB}$ and TLR4-HIF-1 $\alpha$ feed-forward loops in the regulation of inflammatory responses in glioma. Journal of Molecular Medicine. 2012; 90(1): 67-80.

39. Lai FB, Liu WT, Jing YY, Yu GF, Han ZP, Yang X, Zeng JX, Zhang HJ, Shi RY, Li XY, et al: Lipopolysaccharide supports maintaining the stemness of CD133(+) hepatoma cells through activation of the NF- $\kappa$ B/HIF-1 $\alpha$ pathway. Cancer Lett 378: 131-141, 2016.

40. Patra SK: Dissecting lipid raft facilitated cell signaling pathways in cancer. Biochim Biophys Acta 1785: 182-206, 2008.

41. Wickström SA, Alitalo K and Keski-Oja J: Endostatin associates with lipid rafts and induces reorganization of the actin cytoskeleton via down-regulation of RhoA activity. J Biol Chem 278 : 37895-37901, 2003.

42. Chansrichavala P, Chantharaksri U, Sritara P, Ngaosuwankul N and Chaiyaroj SC: Atorvastatin affects TLR4 clustering via lipid raft modulation. Int Immunopharmacol 10: 892-899, 2010.

43. Das S, Alhasson F, Dattaroy D, Pourhoseini S, Seth RK, Nagarkatti M, Nagarkatti PS, Michelotti GA, Diehl AM, Kalyanaraman B and Chatterjee S: NADPH oxidase-derived peroxynitrite drives inflammation in mice and human nonalcoholic steatohepatitis via TLR4-Lipid raft recruitment. Am J Pathol 185: 1944-1957, 2015.

44. GorudkoIV,Mukhortava AV,CaraherB, Ren M,CherenkevichSN, Kelly GM and Timoshenko AV: Lectin-induced activation of plasma membrane NADPH oxidase in cholesterol-depleted human neutrophils. Arch Biochem Biophys 516: 173-181, 2011.

45. Bieberich E: It's a lipid's world: Bioactive lipid metabolism and signaling in neural stem cell differentiation. Neurochem Res 37: 1208-1229, 2012.

46. Eum SY, Andras I, Hennig B and Toborek M: NADPH oxidase and lipid raft-associated redox signaling are required for PCB153-induced upregulation of cell adhesion molecules in human brain endothelial cells. Toxicol Appl Pharmacol 240: 299-305, 2009.

47. Gribar SC, Anand RJ, Sodhi CP and Hackam DJ: The role of epithelial Toll-like receptor signaling in the pathogenesis of intestinal inflammation. J Leukoc Biol 83: 493-498, 2008.

48. Tanaka T, Legat A, Adam E, Steuve J, Gatot JS, Vandenbranden M, Ulianov L, Lonez C, Ruysschaert JM, Muraille E, et al: DiC14amidine cationic liposomes stimulate myeloid dendritic cells through Toll-like receptor 4. Eur J Immunol 38: 1351-1357, 2008.

49. Kim D and Kim JY: Anti-CD14 antibody reduces LPS responsiveness via TLR4 internalization in human monocytes. Mol Immunol 57: 210-215, 2014

50. Campbell JS, Riehle KJ, Brooling JT, Bauer RL, Mitchell C and Fausto N: Proinflammatory cytokine production in liver regeneration is Myd88-dependent, but independent of Cd14, Tlr2, and Tlr4. J Immunol 176: 2522-2528, 2006.

(i) (5) This work is licensed under a Creative Commons car No Attribution-NonCommercial-NoDerivatives 4.0 International (CC BY-NC-ND 4.0) License. 